\begin{tabular}{l} 
MIMESIS \\
Universitas \\
Ahmad Dahlan \\
VOL. 3. No. 1, Januari 2022 \\
\hline
\end{tabular}

\title{
JEJAK KOLONIAL DAN PERAN ORIENTALISME DALAM KUMPULAN CERPEN TEH DAN PENGHIANAT KARYA IKSAKA BANU
}

\author{
Baiq Annisa Yulfana Nalurita
}

Fakultas Ilmu Budaya, Universitas Gadjah Mada

Yogyakarta, Indonesia

nalurita020@gmail.com

\section{Tristanti Apriyani}

Sastra Indonesia, Fakultas Sastra, Budaya, dan Komunikasi,_Universitas Ahmad Dahlan tristanti.apriyani@idlitera.uad.ac.id

Article history

Received 21 September 2021

Revised 28 January 2022

Accepted 29 January 2022

Keywords

Orientalism

Colonial

Short story
The colonial period was the planting of orientalist concepts towards the East, where the differences between East and West were very much shown. This of course did not escape the views of several Indonesian writers and writers who then tried to record this phenomenon in their literary works. One of the Indonesian writers, Iksaka Banu, who discusses the conflict between the natives and the Dutch, the Dutch and ethnic Chinese, to the conflict between the Dutch and the Dutch in various experiences and one of them is Iksaka Banu's latest collection of short stories entitled Teh dan Penghianat which was just published in 2019. This research using qualitative descriptive method aims to describe the form and role of orientalism in the collection of Teh and the traitor by Iksaka Banu by taking two short stories as material for analysis, namely 'Teh dan Pengianat' and 'Belenggu Emas'. The data collection technique was carried out by document study techniques in short stories, namely by collecting data in the form of document archives, including books and journals. Meanwhile, the data triangulation process in the form of theoretical triangulation, data source triangulation and researcher triangulation, was carried out by the author to check the validity of the data. By using the theory put forward by Edward Said, this research concludes that in the short story Teh dan Pengtangan, there can be found several depictions of the East in the context of orientalism which symbolized by indigenous and ethnic Chinese. Meanwhile, in the short story Belenggu Emas, the depiction of the east in the context of orientalism is described as an indigenous community that needs to be improved or educated.

This is an open access article under the CC-BY-SA license.

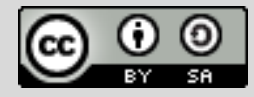

\section{INFO ARTIKEL}

\section{Article history}

Diterima 21 September 2021

Direvisi 28 Januari 2022

Accepted 29 Januari 2022

Kata Kunci

Orientalisme

Kolonial

Cerpen

\section{ABSTRAK}

Masa kolonial adalah puncak penanaman konsep-konsep orientalis terhadap Timur, di mana perbedaan antara Timur dan Barat amat diperlihatkan. Hal ini tentu saja tidak luput dari pandangan beberapa sastrawan dan penulis Indonesia yang kemudian berusaha merekam fenomena tersebut dalam karya sastranya. Salah satu penulis Indonesia Iksaka Banu yang mengetengahkan konflik antara pribumi dan Belanda, Belanda dan etnis Tionghoa, hingga konflik antara Belanda dan Belanda dalam berbagai karyanya dan salah satu diantaranya adalah kumpulan cerpen terbaru Iksaka Banu berjudul Teh dan Penghianat yang baru diterbitkan 2019 lalu. Penelitian yang menggunakan metode deskriptif kualitatif ini bertujuan untuk menguraikan bentuk serta peran orientalisme dalam kumpulan Teh dan Penghianat karya Iksaka Banu dengan mengambil dua cerpen sebagai bahan analisis yakni 'Teh dan Pengianat' dan 'Belenggu Emas'. Teknik pengumpulan data dilakukan dengan teknik studi dokumen dalam cerpen, yaitu dengan cara mengumpulkan data berupa arsip-arsip dokumen, termasuk buku-buku dan jurnal-jurnal. Sementara itu proses triangulasi data berupa triangulasi teori, triangulasi sumber data dan triangulasi peneliti, dilakukan penulis untuk mengecek keabsahan data. Dengan menggunakan teori yang dikemukakan Edward Said penelitian ini menghasilkan kesimpulan bahwa dalam cerpen Teh dan Penghianat dapat dijumpai beberapa penggambaran Timur dalam konteks orientalisme yang disimbolkan melalui pribumi dan etnis Tionghoa. Sementara dalam cerpen Belenggu Emas penggambaran timur dalam konteks orientalisme digambarkan sebagai masyarakat pribumi yang perlu diperbaiki atau dididik.

This is an open access article under the CC-BY-SA license. 


\section{PENDAHULUAN}

Kolonialisme menjadi suatu kenangan pahit yang meninggalkan trauma tersendiri bagi berbagai bangsa di setaip belahan dunia. Kolonialisme pada hakikatnya adalah suatu kegiatan penguasaan terhadap sumberdaya pada suatu negara atau tanah jajahan. Kolonialisme adalah sistem di mana suatu negara menjalankan politik pendudukan atau penjajahan. Aktifitas kolonial di Indonesia sangat identik dengan kedatangan bangsa Belanda atau yang lebih khusnya VOC yang diawali dengan tujuan perdagangan dan secara perlahan membangun kekuatan serta pengaruhnya di Bumiputra.. Kegiatan penguasaan dengan berbagai penaklukan dan tindak kekerasan di Bumiputra meninggalkan trauma amat dalam pada diri bangsa Indonesia. Citra negatif menjadi hal yang tidak dapat dihindari dan seolah selalu melekat pada diri bangsa Belanda dalam kaca mata bangsa Indonesia hingga hari ini. Hal ini memunculkan sebuah gerakan perlawanan dari masyarakat terjajah terhadap kolonial. Untuk memperlancar penguasaan terhadap bidang ekonomi, kaum penjajah juga menebarkan hegemoni di daerah jajahannya. Hegemoni menjadi salah satu jalan lain untuk secara tidak langsung mengendalikan dan membentuk suatu masyarakat menjadi seperti apa yang diinginkan penjajah tanpa melalui jalan kekerasan. Hegemoni dalam hal ini diartikan sebagai sebuah bentuk dominasi dengan tidak hanya mengandalkan penguasaan namun juga menanamkan pengaruh yang dapat membujuk masyarakat untuk dapat patuh pada mereka yang berkuasa. Menurut Salamini sebagaimana yang dikutip (Harjito, 2014: 13) sebelum menguasai negara, manusia harus menguasai dahulu pikiran, menguasai kesadaran.

Apabila diamati lebih jauh, Belanda sebagai bangsa yang pernah menjajah di tanah Bumiputra tidak hanya melakukan penjajahan namun juga hegemoni. Belanda memiliki pengaruh yang cukup banyak dalam mengatur berbagai sistem dan struktur yang ada di tanah Bumi putra pada masanya. Melakukan kegiatan kolonialisasi satu setengah abad lamanya membuat Belanda mampu mempengaruhi banyak aspek kehidupan masyarakat pribumi di Indonesia. Berbagai aturan, struktur pemerintahan bahkan struktur masyarakat, perekonomian, perdagangan hingga sistem pendidikan mampu dikuasai oleh Belanda sebagai kaum kolonial yang memiliki masa pendudukan paling lama dibandingkan bangsa lainnya. Hegemoni dicapai bila suatu kelompok sosial tertentu menjadi kekuatan yang menyatukan dan mengarahkan semua kelompok sosial lain (Said, 2014: 13). Berakhirnya masa penjajahan Belanda nyatanya tidak kemudian membuat bangsa Indonesia terlepas dari pengaruh-pengaruh kolonialisasi. Indonesia tidak dapat dikatakan sebagai negara yang betul-betul merdeka, kemerdekaan bagi bangsa Indonesia hanyalah kemerdekaan raga, karena nyatanya pola pikiran bangsa Indonesia masih terjajah oleh wacana-wacana Barat yang ditinggalkan kaum kolonial. Orientalisme menjadi salah satu wacana Barat yang masih amat melekat dalam diri bangsa Indonesia.

Aktifitas kolonialisme bangsa Barat sudah sangat lama berakhir akan tetapi pengaruh yang ditinggalkannya masih sangat membekas dan mempengaruhi berbagai sisi dan pola kehidupan masyarakat Timur-yang dalam hal ini Indonesia. Jejak-jejak pengaruh kolonialisme masih dapat dilihat dalam berbagai tataran kehidupan masyarakat Timur baik dari perilaku hingga konsep berpikir dan cara memandang sesuatu. Kepentingan kolonialisme memaksa bangsa kolonial tidak hanya sekedar melakukan penaklukan wilayah akan tetapi juga dituntun untuk menaklukkan mental bangsa jajahannya. Menanamkan wacana-wacana orientalis hingga kealam bawah sadar bangsa jajahannya adalah cara kerja kolonial untuk menaklukkan mental bangsa jajahannya. orientalisme adalah wacana-wacana yang dihadirkan Barat untuk mendeskripsikan baik dirinya taupun Timur. Wacana orientalisme sangat identik dengan deskripsi penggambaran perbedaan antara Timur dan Barat di mana Barat digambarkan sebagai bangsa yang maju dan Timur sebagai bangsa yang terbelakang. Said (2001:311) menyebutkan 


\begin{tabular}{l} 
MADESIS \\
Universitas \\
Ahmad Dahlan \\
VoL. 3o. 1, Januari 2022 \\
\hline
\end{tabular}

bahwa orientlisme adalah cara penulisan, pewawasan, dan pengkajian yang distrukturasikan (atau diorientalisasikan) didominasi oleh prasangka, perspektif, dan bias-bias idiologi yang dianggap cocok untuk disematkan kepada Timur. Timur diajarkan, diteliti, dan dinilai sedemikian rupa dengan cara-cara tertentu. Bangsa terjajah secara tidak sadar telah menggunakan konsep orientalime untuk memaknai keberadaan mereka dan Timur. Pandangan tentang Timur dan Barat pada akhirnya sejalan dengan apa yang diwacanakan oleh para orientalis.

Orientalisme berhasil memposisikan dirinya sebagai wacana global yang diamini oleh hampir seluruh bangsa, Barat pada akhirnya menjadi pihak pemegang otoritas dalam hal berbicara dan berpendapat. Tradisi semacam ini masih terus berlangsung hingga saat ini, produksi terhadap wacana orientalisme seolah tidak dapat dihentikan. Segala pusat pengetahuan diarahkan pada Barat sebagai kiblat acuan. Timur adalah hasil pengetahua yang diciptakan oleh Barat sedangkan Barat adalah sumber pengetahuan tersebut. Barat tidak perlu kebenaran yang sesungguhnya dalam memproduksi sebuah pengetahuan karena pada dasarnya konsep dari orientalime bukanlah pada bagaimana kebenaran itu namun lebih kepada bagaimana menjadi benar.

Aktifitas kolonialisme yang dilakukan oleh Barat terhadap Timur sedikit tidaknya mempengaruhi sebagian besar pola hidup dan pola pikir bangsa Timur sebagai bangsa yang terjajah. Orientalisme menjadi salah satu wacana yang memegang peran penting dalam menghegemoni bangsa Timur selama proses kolinialisasi. Said (Said, 2001: 311) memaparkan bahwa orientalisme adalah cara penulisan, pewawasan, dan pengkajian yang distrukturasikan (atau diorientalisasikan) didominasi oleh prasangka, perspektif, dan bias-bias idiologi yang dianggap cocok untuk disematkan kepada Timur.

Bertolak dari hal tersebut dapat dilihat bagaimana Barat merupakan agen yang berperan aktif menghasilkan wacana dan pengetahuan, sedangkan Timur adalah pihak yang berperan pasif (dideskripsikan). Orientalisme merupakan suatu aliran penafsiran yang menjadikan Timur, peradabannya, orang-orangnya, dan lokalitasnya sebagai objek interpretasi (Said, 2001: 312). Wacana orientalisme sangat identik dengan deskripsi penggambaran perbedaan antara Timur dan Barat di mana Barat digambarkan sebagai bangsa yang maju dan Timur sebagai bangsa yang terbelakang. Memandang dirinya sebagai bangsa yang mampu, beradap dan berintelektual tinggi membuat Barat merasa memiliki kekuasaan lebih dalam mendeskripsikan dirinya dan Timur.

Said (2001: 309) menyebutkan bahwa salah satu hal yang paling mempengaruhi orientalisme hingga mampu bertahan sampai saat ini adalah rasa konfrontasi yang sangat konstan dari orang-orang Barat yang berurusan dengan Timur. Otoritas Barat untuk dapat berbicara dan mendefinisikan baik dirinya maupun bangsa lain tercipta atas dukungan berbagai sistem yang dimilikinya. Segala kekuatan yang dimiliki Barat baik dalam politik, pemerintahan, militer, budaya hingga instusi pendidikan dikerahkan untuk menjaga wacanawacana orientalisme yang menggambarkan perbandingan antara Timur dan Barat tersebut. Orientalis akhirnya muncul sebagai suatu paham dengan kekuatan yang amat besar yang membentuk gambaran antara Timur dan Barat dan hingga hari ini masih menghegemoni masyarakat diberbagai belahan dunia baik secara sadar ataupun tidak.

Wacana orientalisme banyak menghadirkan perbandingan-perbendingan antara Timur dan Barat di mana Barat selalu digambarkan dengan citra yang positif sedangkan Timur digambarkan dengan citra yang cenderung negative. Konsep Barat sebagai bangsa yang maju, beradap dan berintelektual tinggi sedangkan Timur sebagai bangsa yang terbelakang, penuh mistis, dan tidak bermoral adalah pandangan-pandangan yang dibentuk sendiri oleh Barat dengan berbagai kekuatan sistem yang mendukungnya. Di samping itu orientalisme juga 


\begin{tabular}{l} 
MADESIS \\
Universitas \\
Ahmad Dahlan \\
VoL. 3o. 1, Januari 2022 \\
\hline
\end{tabular}

merupakan satu kawasan minat yang sepenuhnya dikontrol oleh peziarah-peziarah, perusahaan-perusahaan dagang, pemerintah ekspedisi militer, pembaca novel dan kisah-kisah petualangan yang eksotik, sejarawan alam, dan pengunjung tempat-tempat suci yang menganggap Timur sebagai jenis ilmu mengenai tempat, bangsa-bangsa, dan peradaban yang eksotik (Said, 2001: 312-313).

Bertolak dari apa yang disampaikan Gramsci, orientalisme mengambil kedua peran intelektual tersebut, di mana institusi pendidikan turut ikut mempertahankan produksi wacana orientalis dan bersamaan dengan itu orientalis juga mengambil peran melalui hirarki sosial yang diantaranya salah satunya berupa aktifitas kolonialisme. Seperti yang telah disebutkan sebelumnya, orientalisme sebagai identitas komulatif dan identitas bersama di mana hal tersebut memiliki relasi yang kuat dengan keilmuan tradisional, lembaga kemasyarakatan, dan karya-karya tulis tertentu yang mana dalam relasi tersebut intelektual memainkan peran yang penting (Said, 2014: 1-2).

Konsep-konsep orientalisme mengambil peran yang cukup besar dalam membentuk pola pikir dan cara pandang baik bangsa Barat sebagai agen yang memproduksi wacana maupun bangsa Timur sebagai pihak yang dideskripsikan. Masa kolonial adalah puncak penanaman konsep-konsep orientalis terhadap Timur, di mana perbedaan antara Timur dan Barat amat diperlihatkan, hal ini tentu saja tidak luput dari pandangan beberapa sastrawan dan penulis Indonesia yang kemudian berusaha merekam peristiwa sejarah yang dialami bangsa Indonesia (Pratiwi \& Apriyani, 2020: 67).

Salah satu penulis Indonesia Iksaka Banu, banyak mengambarkan kilas balik kondisi serta konflik sosial pada masa kolonialisasi Belanda dalam karya-karyanya. Menjadi penulis yang secara rutin mengangkat konflik kolonialisme membuat tulisan Iksaka Banu tidak lepas dari berbagai gambaran konsep orientalisme. Mengangkat konflik antara pribumi dan Belanda, Belanda dan etnis Tionghoa, hingga konflik antara Belandan dan Belanda menjadi gambaran yang selalu disuguhkan oleh Ikasa Banu dalam berbagai karyanya salah satu diantaranya adalah kumpulan cerpen terbaru Iksaka Banu berjudul Teh dan Penghianat yang baru diterbitkan 2019.

Tiga konflik utama yang telah disebutkan sebelumnya merupakan garis besar gambaran dari cerpen-cerpen dalam Teh dan Pengianat. Penggambaran konflik semacam itu yang kemudian membuka ruang tersendiri bagi wacana orientalisme untuk mengambil tempat pada sebuah karya sastra. Peran-peran orientalisme pada akhirnya ikut berkontestasi membangun alur dari sebuah karya sastra.

Dalam kumpulan cerpen Teh dan Penghianat ditemukannya beberapa wacana orientalisme yang dinarasikan penulis dalam karyanya beberapa diantaranya adalah bagaimana penggambaran Timur dalam konteks orientalisme disimbolkan melalui tokoh-tokoh pribumi dan Tionghoa. Selain itu, terdapat pula narasi-narasi yang menggambarkan Barat sebagai bangsa yang maju sedangkan Timur sebagai bangsa yang lambat dan terbelakang. Penelitian akan difokuskan pada bentuk serta peran orientalisme dalam kumpulan cerpen Teh dan Penghianat karya Iksaka Banu dengan mengambil dua cerpen sebagai bahan analisis yakni 'Teh dan Pengianat' dan 'Belenggu Emas'. Kedua Cerpen tersebut mengandung wacanawacana orientalisme yang menggambarkan baik Timur maupun Barat dalam dua sudut pandang yang berbeda. Maka dalam hal ini terdapat dugaan bahwa kumpulan cerpen Teh dan Penghianat karya Iksaka Banu merupakan salah satu contoh dari sekian karya sastra yang masih memproduksi wacana orientalisme. 


\section{METODE}

Penelitian ini merupakan penelitian deskriptif kualitatif. Menurut Moleong (2018) yang juga dikutip Apriyani \& Cahyani (2021: 235) data deskriptif berbentuk diksi tertulis mengenai kondisi dan fenomena individe maupun kelompok yang diamatinya. Fakta dan karakteristik objek yang diteliti secara otomatis dideskripsikan secara tepat di dalam penelitian deskriptif. Metode kualitatif juga secara keseluruhan memanfaatkan cara-cara penafsiran yang penyajiannya dalam bentuk deskripsi (Ratna, 2018: 46). Metode pengumpulan data dilakukan dengan metode simak catat yang diawali dengan mengumpulkan data-data teoritik melalui berbagai referensi bacaan kemudian dilanjutkan dengan pengumpulan data riset melalui objek material penelitian yang dalam hal ini adalah kumpulan cerpen Teh dan Penghianat karya Iksaka Banu.

\section{PEMBAHASAN}

\section{Orientalisme dalam Kumpulan Cerpen Teh dan Penghianat}

Dalam kumpulan cerpen Ikasaka Banu yang belum lama diterbitkan berjudul Teh dan Penghianat, Iksaka Banu kembali mengangkat isu-isu kolonialisme dalam cerpen-cerpennya kali ini setelah sebelumnya telah berhasil menerbitkan kumpulan cerpen berjudul Semua untuk Hindia dengan isu kolonialisme yang tidak jauh berbeda. Projek ini mengulas kembali kehidupan masyarakat Hindia-Belanda pada masa kolonialisme masih berkuasa. Penggambaran situasi sosial serta pandangan-pandangan kolinialis terhadap pribumi tidak luput dari narasi penulis.

Jika ditarik secara garis besar, maka akan dapat ditemui tiga konflik utama yang narasikan oleh penulis dalam kumpulan cerpennya kali ini. Konflik-konflik tersebut yakni antara sesama Belanda yang dalam hal ini menghadirkan sosok tokoh Belanda dalam dua sudut pandang yakni mewakili wacana orientalis dan yang berusaha bersikap rasional dan cendrung berlawanan dengan konsep orientalis dan kolonialisme. selain itu ada pula penggambaran konflik antara Belanda dan Pribumi serta Belanda dengan etnis Tionghoa di Hindia-Belanda. Dua konflik terakhir tentu menggambarkan perjuangan Timur melawan otoritas dan kekuasaan kolonialisme di tanah Hindia-Belanda, di mana dalam hal ini dapat ditemui peran orientalisme dalam penggambaran tokoh-tokoh pribumi dan etnis Tionghoa. Dalam pembahasan kali ini akan digunakan dua cerpen untuk melihat gambaran peran-peran orientalis dalam kumpulan cerpen Iksaka Banu kali ini yakni cerpen berjudul Teh dan Penghianat dan Belenggu Emas.

Dalam cerpen berjudul Teh dan Penghianat yang judulnya juga digunakan sebagai acuan untuk kumpulan cerpen Iksaka Banu kali ini, menceritakan konflik antara etnis Tionghoa dan Belanda berupa usaha perebutan lahan teh yang disebabkan oleh kesewenangan kepala perkebunan Belanda terhadap etnis Tionghoa yang kemudian ikut melibatkan pribumi. Konflik diawali dengan perdebatan antara seorang kapten tentara Belanda bernama Simon Vastgebonden dengan seorang deputi perkebunan Belanda bernama Karel Wijnand yang datang dengan tujuan ingin menyewa beberapa tentara kapten Simon untuk mengawalnya dalam perjalanan menuju Batavia. Dalam pertemuan ini terjadi perdebatan antara kapten Simon yang memandang bahwa pemberontakan etnis Tionghoa disebabkan oleh perlakuan pemerintah kolonial yang sering telat membayar upah pekerja perkebunan bahkan bayaran yang diperoleh terkadang tidak sesui perjanjian awal, serta perlakuan kepala perkebunan yang sering menghukum pekerja diluar batas wajar. Berbeda dengan kapten Simon, Karel cendrung memandang pemberontakan etnis Tionghoa sebagai bentuk keberutalan dan sikap tidak tau terimakasi orang-orang Tionghoa terhadap Belanda. Karen cendrung memandang Tionghoa 


\begin{tabular}{l} 
MADESIS \\
Universitas \\
Ahmad Dahlan \\
VoL. 3o. 1, Januari 2022 \\
\hline
\end{tabular}

sebagai sekelompok orang yang beringas, tidak tau balas budi atas perlindungan dan lapangan kerja yang disediakan Belanda untuk mereka yang kemudian harus didisiplinkan kembali.

Etnis Tionghoa pada kenyataanya telah mendapatkan diskriminasi baik dari kolonial maupun pribumi sendiri, hal tersebut tentunya tidak mengecualikan Tionghoa sebagai salah satu bangsa yang didefinisi sebagai Timur dalam wacana orientalisme. Pembagian kelompok yang dilakukan Belanda terhadap Masyarakat Hindi-Belanda di mana terdapat pemecahan tiga kelompok masyarakat yakni masyarakat Eropa, Timur-asing, dan Bumiputra. Kelompok Timur-asing di sini antara lain Tionghoa, Arab dan etnis-etnis timur diluar pribumi lainnya yang berada di Nusantara (Sugitario, 2008: 2-3). Berdasarkan pengelompokan tersebut Tionghoa tentu masih menjadi bagian dari masyarakat Timur Asia. Pikiran-pikiran Karel terhadap etnis Tionghoa secara tidak langsung mengulang definisi masyarakat Timur Semit yang dihadirkan dalam wacana orientalis sebagai bangsa yang tidak beradap, pemberontak dengan peradaban yang terbelakang. Karel dalam hal ini menjadi simbolisasi orientalisme sedangkan Simon cenderung menyimbolkan rasionalitas di mana wacana orientalisme tidak benar-benar berpengaruh baginya.

Di tengah perlawanan Tionghoa terhadap Belanda, tokoh Pribumi kemudian dihadirkan dalam bentuk relasi kerja dengan Belanda untuk menumpas pemberontakan-pemberontakan di Hindia-Belanda yang salah satunya adalah pemberontakan etnis Tionghoa. Tokoh Senon dihadirkan sebagai seorang pribumi yang dahulunya merupakan tangan kanan pangeran Diponogoro saat perang Jawa melawan kolonial yang kemudian mendatangi Belanda untuk meminta pekerjaan karena masalah ekonomi. Senon meninggalkan junjungannya (pangeran Diponogoro) karena perekonomian yang kurang baik untuk mencari peruntuan yang lebih baik bagi dirinya dan beberapa org kelompoknya. Tindakan Senon tersebut secara tidak langsung menggambarkan ketidakmampuan pribumi untuk mengatasi permasalahannya sendiri. Wacana Timur membutuhkan Barat kembali terulang melalui penggambaran tersebut, bahwa TimurPribumi bukan bangsa cukup mampu untuk mengatasi permasalahannya sehingga dibutuhkan Barat untuk mengeluarkan Timur dari situasi tidak menguntungkannya.

Dalam cerpen Teh dan Penghianat dapat dijumpai beberapa penggambaran Timur dalam konteks orientalisme yang disimbolkan melalui pribumi dan etnis Tionghoa. Penggambaran tersebut diantaranya: pertama, Timur yang membutuhkan Barat, seperti yang telah dipaparkan sebelumnya berkaitan dengan kehadiran tokoh Senon. Kedua, Barat membutuhkan Timur sebagai pekerja atau bawahan, tersebut terlihat dalam salah satu kutipan artikel yang dibaca oleh kapten Simon:

"Teh berasal dari negeri Cina. Masuk ke Hindia Belanda tahun 1684 dalam bentuk biji teh dari Jepang, lalu pada tahun 1826, teh dikembangkan di S'Lands Plantentuin Buitenzorg. Tak lama kemudian Jacobus Isidorus Loudewijk Levian Jacobson menanam teh secara besar-besaran di Banyuwangi dan di kebun teh di Wanayasa dianggap berhasil membuka jalan bagi usaha perkebunan teh di Pulau Jawa untuk meningkatkan mutu produksi. Jacobson mengambil buruh Cina dari Kerawang dan Batavia. Ia juga mendatangkan 15 buruh langsung dari Negeri Cina. Tujuh diantaranya pakar teh." (Banu, 2019:38). 


\begin{tabular}{lc}
\hline MIMESIS & MIM \\
Universitas \\
Ahmad Dahlan & VoL. 3. No. 1, Januari 2022 \\
\hline
\end{tabular}

Dalam hal ini Timur digambarkan berada di bawah otoritas dan dikendalikan atau dikordinir oleh Barat, kebutuhan Barat terhadap Timur tidak kemudian mengubah posisi Barat sebagai bansa yang berkuasa. Kemampuan intelektual serta dukungan berbagai sistem seperti militer, politik dan institusi pendidikan membuat Barat terus hadir sebagai kekuatan yang tidak dapat digulirkan. Ketiga, kolonial membutuhkan pribumi (Timur) untuk memperkuat kekuasaannya. Timur yang membutuhkan Barat untuk membentuk relasi-relasi kerja dengan kolonial yang mana kemudian Pribumi ditempatkan sebagai alat untuk memperkuat kekuasaan kolonial. Peran Senon dalam meredam berbagai pemberontakan di Hindia-Belanda merupakan gambaran yang ditampilkan penulis dalam cerpen Teh dan Pengiatat. Memiliki konflik yang tidak jauh berbeda dengan Teh dan Penghianat, dalam cerpen Belenggu Emas juga terdapat penggambaran konflik antara Belanda dan Belanda di mana dimunculkan melalui tokoh pasangan suami istri Theodoor Makenburg dan Cornelia.

Theodoor Makenburg merupakan seorang insinyur yang disalah satu perusahaan milik ayah Cornelia atau biasa juga disebut sebagai Nellie yang sangat menjunjung tinggi status sosialnya sebagai bangsa Barat. Theo memandang bahwa bangsanya tidak seharusnya disamakan dengan orang Timur bodoh, bagi Theo terdapat batasan-batasa yang tidak seharusnya dilewati oleh bangsa Barat baik cara bertutur, berprilaku, hingga cara berpakaian. Perbedaan sudut pandang tersebut membuat Theo cendrung membatasi Nellie dalam berbagai hal yang akhirnya membawa Nellie pada sebuah perjalanan menuju Kota Gadang untuk mengunjungi Roehana Koeddoes seorang perempuan pribumi pemilik salah satu sekolah kerajianan dan pemimpin salah satu surat kabar khusus wanita yang sangat menginspirasi Nellie.

Cerpen Belenggu Emas menceritakan konflik antara suami istri berkebangsaan Belanda yang memiliki pandangan berbeda dalam menyikapi tradisi, status sosial hingga pandangan terhadap pribumi. Diceritakan dari sudut pandang orang pertama yakni Cornelia atau Nellie perempuan Belanda yang tidak pernah memandang kebelandaanya sebagai kaum Barat merupakan status yang perlu diagung-agungkan, sosok perempuan yang memiliki jiwa sosial yang tinggi dan sangat mengagumi perempuan-perempuan yang melalukan gerakan-gerakan sosial seperti Reohana dan nyonya Westenenk. Cerita yang berpusat pada konflik perbedaan pandangan antara Nellie dan suaminya Theo.

Penggambaran dalam cerpen Belenggu Emas baik dari situasi dan kondisi wilayah hingga tradisi dan masyarakat Hindia-Belanda memperlihatkan pandangan Barat terhadap Timur. Orientalisme merupaka deskripsi Barat terhadap Timur dari sudut pandang Barat. Penekanan terhadap steriotip ketimuran yang disampaikan toko Nellie sebagai sudut pandangan pencerita dalam cerpen tersebut memperlihatkan adanya permainan wacana orientalisme yang ikut serta membangun jalannya cerita. Hadirnya tokoh Theo menyimbolkan superioritas Belanda terhadap pribumi, penulis dalam hal ini menghadirkan tokoh-tokoh Belanda dari dua sudut pandang yang berbeda seperti dalam cerpen sebelumnya untuk memulai suatu konflik dan perdebatan panjang tentang identitas Kebelandaannya sebagai penguasa yang berstatus sosial lebih tinggi dari pribumi. Theo dihadirkan sebagai tokoh Belanda yang amat menjunjung tinggi status sosialnya sebagai bangsa Barat yang berpengetahuan dan berkedudukan lebih tinggi, yang harus menjaga batasan-batasannya agar tidak sama dengan pribumi. Pandangan terhadap pribumi sebagai masyarakat yang bodoh, laban serta perlu didik sehingga menjadi lebih beradap menjadi alasan Theo untuk menjaga batasan-batasannya sebagai bangsa Barat yang berposisi sebagai pemimpin bagi pribumi. Keberadaan Theo seperti halnya Karel dalam Teh dan Penghianat menggambarkan wacana orientalisme dalam perbandingan antara Timur dan Barat. 


\begin{tabular}{lc}
\hline MIMESIS & MIM \\
Universitas \\
Ahmad Dahlan & VoL. 3. No. 1, Januari 2022 \\
\hline
\end{tabular}

Batasan-batasan yang selalu ditekankan tokoh Theo dalam hal ini bersumber dari pandangannya tentang perbedaan posisi atau status sosial yang ditunjukkan dari budaya dan tradisi mereka, Belanda tidak boleh berperilaku atau bergaul layaknya pribumi pada umumnya. Terlihat pada salah satu bagian di mana Theo mempesoalkan cara berpakaian Nellie yang terlalu mengikuti cara hidup hingga cara berpakaian pribumi. bagaimana Theo kemudian meminta istrinya yang seolah tidak mempermasalahkan hal tersebut untuk memindahkan sudut pandangnya.

"coba kamu pindah dulu sudut pandangmu ke pihak kita."

"The white man burden's. ingat? Kita ingin merubah keadaan, merubah mereka. Bukan berubah menjadi mereka. Bukan merendahkan diri dihadapan para babu, jongos, atau bendi. Aku tak pernah suka orang inggir tapi aku setuju pendapat Raffles dan Kipling. Orang kulit putih harus jadi teladan dalam segala hal. Termasuk dalam hal berbusana. Coba lihat, meski rafles sangat memahami budaya daerah, bahkan menulis buku tentang Hindia ia melarang pejabat memakai kain atau mengunyah sirih..." (Banu, 2019: 113).

Kutipan percakapan Theo berikut meperlihatkan pandangan terhadap perbedaan antara Timur dan Barat, timur digambarkan sebagai masyarakat yang perlu diperbaiki dan didik dan orag eropa sebagai bangsa Barat tidak semestinya menjadi seperti mereka. Konsep orientalis tentang perbedaan Barat dan Timur membawa Theo pada persetujuan pandangan Raffles walau ia tidak pernah menyukai orang Inggris. Bertolak dari hal tersebut gambaran superior Barat terhadap Timur mulai diperlihatkan. Pada bagian lain wacana orientalisme kembali dimainkan, yakni gambaran Timur yang lamban. Dalam percakaan antara Nellie dan Westenenk terdapat pernyataan dari Westenenk yang mengatakan bahwa Hindia-Belanda tidak sama dengan eropa, segala hal cenderung berjalan lebih lambat di Hindia-Belanda. Orang Belanda bahkan tidak bisa menolong diri mereka dari situasi tersebut, hingga waktu ikut berjalan lebih lambat untuk mereka.

Ungkapan Westenenk yang dalam cerpen diceritakan sebagai perempuan dengan jiwa sosialis yang tinggi dan banyak ikut dalam berbagai pergerakan penyejahteraan perempuan pribumi tidak dapat lepas dari wacana orientalis. Penggambaran yang disampaikan Westenenk jika ditarik benangmerahnya akan mengarah pada gagasan pribumi sebagai masyarakat yang lamban, suka membuang-buang waktu, berbeda dari orang eropa yang mengerjakan segala hal dengan gesit dan perhitungan waktu. Fakta bahwa orang Eropa yang berada di Hindia-Belanda tidak dapat bergerak gesit layaknya ketika mereka berada di negaranya seolah dikembalikan lagi dalam bentuk penangguhan kesalahan kepada pribumi, kondisi pribumi yang lamban, bodoh dan menyia-nyiakan waktu ikut mempengaruhi cara kerja mereka. Perbedaan-perbedaan yang menempatkan pribumi sebagai Timur dalam pandangan negative merupakan salah satu produksi dari wacana orientalisme Barat. Karya-karya semacam ini pada akhirnya ikut berpartisipasi dalam memroduksi wacana-wacana orientalisme. Sadar ataupun tidak konsep orientalisme telah diterima oleh masyarakat dalam alam bawah sadarnya, sehingga wacana perbandingan semacam ini memiliki kekuatan yang amat besar dan dianggap benar bahkan hingga ditingkat global.

\section{KESIMPULAN}

Perbandingan antara Timur dan Barat dalam wacana orientalisme seolah tidak dapat dihindari. Timur sebagai bangsa yang dideskripsikan tanpa sadar ikut mengamini dan mengambil peran dalam produksi wacana orientalime. Trauma serta kebencian terhadap kolonialisme nyatanya tidak dapat melepaskan Timur dari konsep-konsep pemikiran 


\begin{tabular}{l} 
MADESIS \\
Universitas \\
Ahmad Dahlan \\
VoL. No. 1, Januari 2022 \\
\hline
\end{tabular}

orientalisme bahkan setelah berpuluh-puluh tahun sejak kepergian kolonial dari tanah Bumiputra. Hal ini membuktikan bahwa kolonialisme tidak hanya datang membawa misi penguasaan terhadap sumber daya di negri jajahannya namun turun menghegemoni pikiranpikiran bangsa jajahannya sehingga bahkan ketika keberadaan mereka sudah tidak ada lagi, konsep-konsep berfikir tersebut masih tetap bertahan. Jejak kolonialisme tidak hanya dapat dilihat daalam bentuk material seperti bangunan, namun juga dapat dilihat dari cara pandang bangsa bekas jajahannya, hingga sistem sosial politik yang dijalankan pada suatu Negara bekas jajahan. Karya-karya sastra pun seolah tidak dapat keluar dari pengaruh wacana-wacana tersebut, di mana gambaran Barat sebagai pusat intelektual dan Timur yang yang membutuhkan Barat muncul bahkan diluar karya-karya bertemakan kolonialisme. Wacana perbandingan antara Timur dan Barat yang menggambarkan Barat sebagai bangsa yang maju dan Timur sebagai bangsa yang terbelakang dan membutuhkan Barat terus diulang. Kumpulan cerpen Teh dan Penghianat karya Iksaka Banu merupakan salah satu contoh dari sekian karya sastra yang masih memproduksi wacana orientalisme, yang mana pada hampir setiap cerpen dalam kumpulan cerpen tersebut mengandung wacana orientalisme.

\section{DAFTAR PUSTAKA}

Apriyani, T., \& Cahyani, V. (2021). Surat edaran dirjen dikti tentang imbauan pembelajaran daring dan sosialisasi undang-undang cipta kerja: analisis wacana kritis. Suar Betang, $16(2), 233-242$.

Banu, I. (2019). Teh dan Penghianat. KPG (Kepustakaan Populer Gramedia).

Harjito. (2014). Hegemoni Gramci dalam sastra Indonesia: Student Hijo, nasionalisme, dan wacana kolonial. UPGRIS Press.

Moleong, L. (2018). Metodologi Penelitian Kualitatif. Remaja Rosdakarya.

Pratiwi, W. A., \& Apriyani, T. (2020). Homo Sacer Orang Pegaten Dalam Novel Kubah Karya Ahmad Tohari ( Perspektif Giorgio Agamben ). Mimesis, I (2), 66-76.

Ratna, N. K. (2018). Teori, metode, dan teknik penelitian sastra. Pustaka Pelajar.

Said, E. (2001). Orientalisme (Terj). Penerbit Pustaka.

Said, E. (2014). Peran Intelektual, Kuliah-kuliah Reith Tahun 1993 (trj). Yayasan Obor Indonesia.

Sugitario, E. (2008). Undang-undang Nomor 12 Tahun 2006 tentang Kewarganegaraan Repbulik Indonesia, dan Undang-undang Nomor 23 Tahun 2006 tentang Administrasi Kependudukan sebagai Perekat Persatuan dan Kesatuan Bangsa. 